\title{
2019 Novel Coronavirus can be detected in urine, blood, anal swabs and
}

oropharyngeal swabs samples

\author{
Liang Peng ${ }^{1,2 \#}$, Jing $\mathrm{Liu}^{1,2 \#}$, Wenxiong Xu ${ }^{1,2 \#}$, Qiumin Luo ${ }^{1,2 \#}$, Keji Deng ${ }^{3}$, Bingliang \\ $\operatorname{Lin}^{1,2^{*}}$, Zhiliang $\mathrm{Gao}^{1,2^{*}}$.
}

Author affiliations:

${ }^{1}$ Department of Infectious Diseases, The 3rd Affiliated Hospital of Sun Yat-sen

University, Guangzhou 510630, Guangdong, China

${ }^{2}$ Guangdong Key Laboratory of Liver Disease Research, The 3rd Affiliated Hospital of Sun Yat-sen University, Guangzhou 510630, Guangdong, China

${ }^{3}$ Jinan University, Guangzhou 510632, Guangdong, China

${ }^{\#}$ These first authors contributed equally to this article.

*Correspondence: Professor Zhiliang Gao, gaozhl@mail.sysu.edu.cn; or Professor Bingliang Lin, lamikin@126.com. Department of Infectious Diseases, Guangdong Key Laboratory of Liver Disease Research, The 3rd Affiliated Hospital of Sun Yat-sen University, Guangzhou 510630, Guangdong, China. 
medRxiv preprint doi: https://doi.org/10.1101/2020.02.21.20026179; this version posted February 25, 2020. The copyright holder for this preprint (which was not certified by peer review) is the author/funder, who has granted medRxiv a license to display the preprint in perpetuity.

All rights reserved. No reuse allowed without permission. 


\begin{abstract}
We tested samples collected from nine patients diagnosed with coronavirus disease 2019 (COVID-19). The virus was found in urine, blood, anal swabs and oropharyngeal swabs. It is the first time for SARS-CoV-2 found in urine, though no urinary irritation was found.
\end{abstract}

\title{
Introduction
}

2019 Novel Coronavirus (SARS-CoV-2) infection outbroke and spread to the world from 2019. By January 28, 2020, a total of 4593 global confirmed cases, of which 4537 were from China, had been reported(1). On January 30, 2020, SARS-CoV-2 infection was declared as a global health emergency by World Health Organization (WHO). The mechanism of SARS-CoV-2 infection and organ invasion are unclear, which directly leads to difficulties and blindness in clinical diagnosis and treatment. We aim to detect SARS-CoV-2 nucleic acid from urine, blood, anal swab and oropharyngeal swab samples. We hope to provide evidences of the multiple organ invasion of the virus and figure out its relation with clinical manifestations.

\section{Methods}

Nine patients confirmed diagnosed with SARS-CoV-2 infection(2) were included in this prospective study. Urine, blood, anal swabs and oropharyngeal swabs from 
enrolled patients were obtained and detected SARS-CoV-2 RNA level by quantitative real-time polymerase chain reaction (qRT-PCR). Patients' demographic data and clinical characteristics were recorded. This study was approved by the institutional review board (IRB) of the Third Affiliated Hospital of Sun Yat-sen University. All patients voluntarily signed an informed consent form approved by the IRB before participation.

\section{Results}

Patient 7, a 31 years old female without any urinary irritation, had positive results of SARS-CoV-2 in both urine and oropharyngeal swab on the $7^{\text {th }}$ day after symptom onset. Patient 1 and 5 had negative results in oropharyngeal swab, on the $10^{\text {th }}$ and $15^{\text {th }}$ day after onset. Patient 8 had three positive results in blood, anal swab and oropharyngeal swab on the $3^{\text {rd }}$ day after onset. Viral load was roughly higher in anal swab than oropharyngeal swab in patient 9 (Table).

Eight of nine patients had an obvious history of epidemiological exposure to SARS-CoV-2. All patients presented with a fever. Other symptoms were cough, sore throat, fatigue and diarrhea. Four patients had a lymphopenia. Elevated C-reactive protein and erythrocyte sedimentation rate were found in 6 and 5 cases respectively. All patients had normal serum levels of procalcitonin, alanine transaminase, creatinine, myocardial enzyme and arterial partial oxygen pressure. 


\section{Discussion}

The pathogenic mechanism of SARS-CoV-2 infection is still unclear. Current evidences indicate that it can invade multiple organ systems, including the respiratory system, digestive system and hematological system(3-5). But whether it can invade the urinary system has not been reported. In our study, urine, blood, anal swab and oropharyngeal swab from 9 patients were retested by qRT-PCR. It is the first time for the SARS-CoV-2 found in urine, though no urinary irritation was found. In addition, the quantity of the virus in the anal swab was closer to that of the oropharyngeal test, and those in the blood and urine were less than that of the oropharyngeal test, indicating that the "clearing effect" of the digestive tract on the virus is not obvious. Nevertheless, the relative symptoms, including diarrhea and urinary irritation did not happen to every patient with virus in anal swab and urine specimens. All samples were negative at the earliest time of the $10^{\text {th }}$ day after onset in that mild patient. Therefore, we believed that SARS-CoV-2 can invade the urinary system, hematological system and digestive system other than the respiratory system, not always with relative symptoms. Mild patients can be self-limiting. This will prompt clinicians to pay attention to the clinical manifestations of multiple systems, even if the corresponding clinical symptoms do not appear. In addition, it is necessary to carry out multiple examinations of various specimens to assess changes in disease and prognosis. 


\section{Funding}

This study was supported by grants from the Natural Science Foundation of China (NSFC) (No. 81570539 and 81873572), Tackling of key scientific and emergency special program of Sun Yat-sen University (SYSU-TKSESP) and Emergency special program for 2019-nCoV of Guangdong province science and technology project (GDSTP-ESP) (2020B111105001).

\section{Declaration of interests}

All authors declare no competing interests.

\section{References}

1. World Health Organization. Situation Report-8. January 28 , 2020.

https://www.who.int/docs/default-source/coronaviruse/situation-reports/20200128-sitr

ep-8-ncov-cleared.pdf?sfvrsn=8b671ce5_2 (accessed February 13, 2020)

2. National Health Commission of the People's Republic of China. Diagnosis and treatment program for 2019 Novel Coronavirus pneumonia. January 22, 2020.

http://www.nhc.gov.cn/xcs/zhengcwj/202001/f492c9153ea9437bb587ce2ffcbee1fa/fil es/39e7578d85964dbe81117736dd789d8f.pdf (accessed February 13, 2020) 
medRxiv preprint doi: https://doi.org/10.1101/2020.02.21.20026179; this version posted February 25, 2020. The copyright holder for this preprint (which was not certified by peer review) is the author/funder, who has granted medRxiv a license to display the preprint in perpetuity.

All rights reserved. No reuse allowed without permission.

3. Michelle L. Holshue, Chas DeBolt, Scott Lindquist, et al. First case of 2019 Novel Coronavirus in the United States. The New England Journal of medicine, January 31, 2020. DOI: 10.1056/NEJMoa2001191.

4. Jasper Fuk-Woo Chan, Shuofeng Yuan, Kin-Hang Kok, et al. A familial cluster of pneumonia associated with the 2019 novel coronavirus indicating person-to-person transmission: a study of a family cluster. The Lancet. January 24, 2020. DOI: 10.1016/s0140-6736(20)30154-9.

5. Chaolin Huang, Yeming Wang, Xingwang Li, et al. Clinical features of patients infected with 2019 novel coronavirus in Wuhan, China. The Lancet. January 24, 2020. https://doi.org/10.1016/S0140-6736(20)30183-5. 
medRxiv preprint doi: https://doi.org/10.1101/2020.02.21.20026179; this version posted February 25, 2020. The copyright holder for this preprint (which was not certified by peer review) is the author/funder, who has granted medRxiv a license to display the preprint in perpetuity.

All rights reserved. No reuse allowed without permission.

Table. Clinical characteristics and qRT-PCR testing for the 4 kinds of specimens of patients infected with SARS-CoV-2§

\begin{tabular}{|c|c|c|c|c|c|c|c|c|c|c|}
\hline & patient 1 & patient 2 & patient 3 & patient 4 & patient 5 & patient 6 & patient 7 & patient 8 & patient 9 & No.(\%) \\
\hline Age, years & 37 & 46 & 27 & 27 & 62 & 30 & 31 & 49 & 41 & \\
\hline Sex & M & $\mathrm{F}$ & $\mathrm{F}$ & $\mathrm{F}$ & $\mathrm{F}$ & M & $\mathrm{F}$ & M & M & \\
\hline Epidemiological history & Yes $^{*}$ & Yes $^{*}$ & Yes $^{*}$ & Yes $^{*}$ & Yes\# & Yes $^{*}$ & Yes $^{*}$ & Yes $^{*}$ & Uncertainty & \\
\hline & & & & & & & & $\begin{array}{l}+ \text { (hyperten } \\
\text { sion, }\end{array}$ & & \\
\hline Underlying disease & - & - & - & - & - & - & - & $\begin{array}{l}\text { hyperthyroi } \\
\text { dism) }\end{array}$ & - & $1(11 \%)$ \\
\hline \multicolumn{11}{|l|}{ Symptoms } \\
\hline Fever & + & + & + & + & + & + & + & + & + & $9(100 \%$ \\
\hline & + & + & + & + & + & + & + & + & & ) \\
\hline Cough & + & + & - & - & + & + & - & + & + & $6(67 \%)$ \\
\hline Sputum Productive & - & + & - & - & - & + & - & + & - & $3(33 \%)$ \\
\hline Dyspnea & - & - & - & - & - & - & - & - & - & 0 \\
\hline Sneezing & - & - & - & - & - & - & - & - & - & 0 \\
\hline Sore throat & - & + & - & + & + & - & - & - & - & $3(33 \%)$ \\
\hline Fatigue & + & - & + & - & - & - & - & - & - & $2(22 \%)$ \\
\hline Diarrhea & - & - & - & - & - & - & - & + & - & $1(11 \%)$ \\
\hline Urinary irritation & - & - & - & - & - & - & - & - & - & 0 \\
\hline $\begin{array}{l}\text { White blood cell } \\
\text { count, } \times 10^{9} / \mathrm{L}\end{array}$ & 4.59 & 4.21 & 4.94 & 5.03 & 7.3 & 5.37 & 3.8 & 4.5 & 4 & \\
\hline Lymphocyte & & & & & & & & & & \\
\hline count, $\times 10^{9} / \mathrm{L}$ & 1.0 & 1.19 & 1.28 & 0.72 & 2.98 & 1.5 & 1.28 & 0.69 & 0.88 & \\
\hline Lymphopenia $\left(<1.1 \times 10^{9} /\right.$ & + & - & - & + & - & - & - & + & + & $4(44 \%)$ \\
\hline
\end{tabular}


medRxiv preprint doi: https://doi.org/10.1101/2020.02.21.20026179; this version posted February 25, 2020. The copyright holder for this preprint (which was not certified by peer review) is the author/funder, who has granted medRxiv a license to display the preprint in perpetuity.

All rights reserved. No reuse allowed without permission.

L)

\begin{tabular}{|c|c|c|c|c|c|c|c|c|c|c|}
\hline C-reactive protein & & & & & & & & & \multirow[b]{2}{*}{$<0.05$} & \\
\hline $\begin{array}{l}\text { concentration, } \mathrm{mg} / \mathrm{L} \\
\text { (normal range } 0-6.0 \text { ) }\end{array}$ & 9.1 & 7.46 & 10.4 & 6.7 & 7.9 & 6.7 & 0.6 & 1.8 & & \\
\hline \multicolumn{11}{|l|}{ Erythrocyte } \\
\hline $\begin{array}{ll}\text { sedimentation } & \text { rate, } \\
\mathrm{mm} / \mathrm{H} \text { (normal range }\end{array}$ & 7 & 37 & 21 & 7 & 31 & 10 & 12 & 18 & 18 & \\
\hline $0-15)$ & & & & & & & & & & \\
\hline \multicolumn{11}{|l|}{ Days from symptom } \\
\hline $\begin{array}{l}\text { onset to sample } \\
\text { collection }\end{array}$ & 15 & 17 & 8 & 3 & 10 & 8 & 7 & 3 & 3 & \\
\hline \multicolumn{11}{|l|}{ qRT-PCR, copies/ml } \\
\hline Oropharyngeal swab & ND & $4.56 \mathrm{E}+02$ & $2.41 \mathrm{E}+04$ & $1.14 \mathrm{E}+04$ & ND & $6.11 \mathrm{E}+03$ & $6.77 \mathrm{E}+04$ & $9.83 \mathrm{E}+03$ & $2.29 \mathrm{E}+04$ & $7(78 \%)$ \\
\hline Blood & ND & ND & ND & $8.04 \mathrm{E}+00$ & ND & ND & ND & $9.11 \mathrm{E}-01$ & ND & $2(22 \%)$ \\
\hline Urine & ND & ND & ND & ND & ND & ND & $3.22 \mathrm{E}+02$ & ND & ND & $1(11 \%)$ \\
\hline Anal swab & ND & ND & ND & ND & ND & ND & ND & $4.47 \mathrm{E}+02$ & $5.42 \mathrm{E}+04$ & $2(22 \%)$ \\
\hline
\end{tabular}

§qRT-PCR, quantitative real-time polymerase chain reaction; SARS-CoV-2, 2019

Novel Coronavirus;

*Epidemiological history was contact with infected patient;

\#Epidemiological history was exposure to epidemic areas; ND, not Detected. 